\title{
Tituli picti on Spanish amphorae
}

\author{
Piero Berni \\ UMR 5140 ASM - Montpellier (Équipe TP2C) / LabEx Archimede ANR-11-LABX-0032-01. \\ Institut Català d'Arqueologia Clàssica (ICAC) \\ <pbernim@gmail.com>
}

Emmanuel Botte

Aix Marseille Univ, CNRS, CCJ, Aix-en-Provence, France

<emmanuel.botte@univ-amu.fr>

\begin{abstract}
This papers deals with the epigraphy on Roman Spanish amphorae. It focuses on the Dressel 20 oil amphorae from Baetica and the salted fish and fish sauces amphorae from Hispania, most of them having been produced (the amphorae and their content) also in Baetica. It offers an overview of the organization and the purposes of these inscriptions.
\end{abstract}

Key words: Roman amphorae; Dressel 20; oil; stamps; painted inscriptions; graffiti; Baetica; Annona; diffusio olearia; Ratio Fisci; salted fish; fish sauces.

\section{Introduction}

Epigraphy on Roman amphora uses different types of inscriptions, mainly graffiti, stamps and tituli picti. The meaning of these rich and diverse records is connected to the fact that the amphora combines two different properties in itself, united in the same object: the duality of the container and the content. This duality offers the key to understanding the unique epigraphic system used on amphorae, and establishing the functional limits of the different classes of inscriptions. There is an epigraphy for the container (graffiti ante cocturam and stamps) and another for the content (tituli picti and graffiti post cocturam). To understand the value and meaning of different types of inscriptions, we need to reflect on the functionality of each record during the life cycle of the Roman amphora, thinking about a secure container to guarantee the transport of foodstuffs.

The four most common types of inscriptions in amphora epigraphy are arranged in a timeline that covers the life cycle of the Roman amphora. Each class constitutes the record of a specific process in its economic development. We differentiate between two economic moments, both subdivided into two phases of activity (Figure 1). Steps A1 and $\mathrm{A} 2$ are attached to the container as activities of the figlina. Steps B1 and B2 are linked to the content and to the phases of trade and consumption.

A common mistake made in studies of amphora epigraphy is to confuse the functional purpose of each of these four classes of inscriptions. For example, the most frequent and debated issue is to consider the stamp as a commercial indicator, or even attribute the role of producers or owners of the packaged product to the freedmen mentioned on the stamp (Grenier 1934; Thévenot 1952; Callender 1965; Remesal 1977-78). The hypothesis that we propose, on the function and meaning of the stamp, as also followed by other researchers, is faithful to the original idea of Dressel who considered the stamp as a factory register, with reference to the owners, managers and workers of the figlina (Dressel 1878; Colls et al. 1977; Mayet 1986; Liou and Tchernia 1994; Berni 2008: 23).

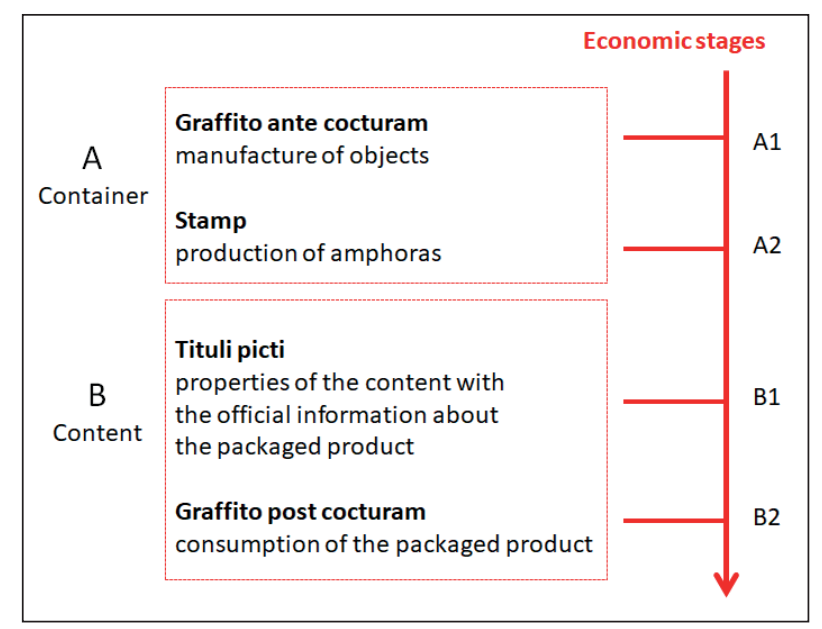

FIGURE 1. FUNCTION AND MEANING OF THE EPIGRAPHY IN THE LIFE CYCLE OF THE ROMAN AMPHORA.

The inscriptions indicating the four economic stages shown in Figure 1 make use of their own ciphered languages, with names, formulas, signs and abbreviations that could only be understood in their entirety from the working environment itself. This 'private' writing was limited to groups of persons practicing the same profession, and would have been incomprehensible for the general public. But this obscure language of the amphora epigraphy can, with some difficulty, be understood and deciphered by researchers, specialized in this field of study.

On the other hand, the value of each of these inscriptions was lost along with its meaning at the time of its economic stage. For example, the stamp ceased to be valid when the 


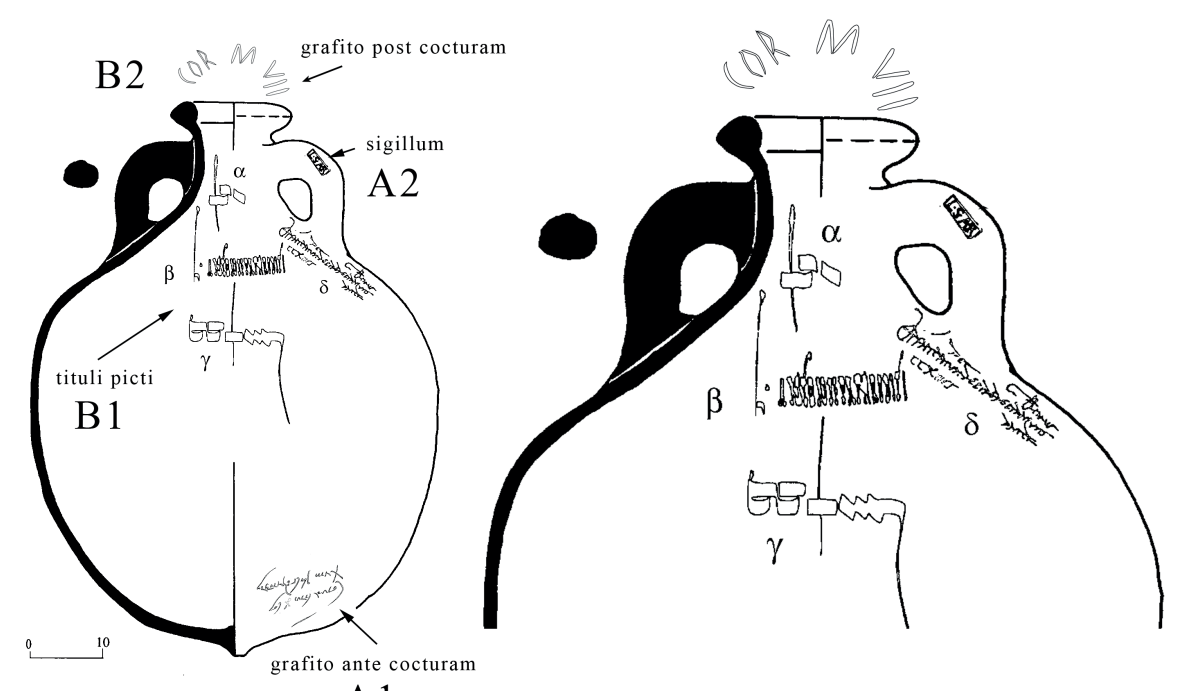

A 1

FIGURE 2. DRESSEL 20 AMPHORA EPIGRAPHIC SYSTEM IN THE MIDDLE OF THE 2ND CENTURY AD.

merchant's agents left the store's warehouse. The original tituli picti written with atramentum lost their utility and legal guarantee with the final sale and consumption of the packaged product. In this way, the passage from one economic stage to another triggered the progressive loss of the function and meaning of the different types of inscriptions. The application of the stamp, a record on the production or commissioning of an amphora set, ended with the function of graffiti ante cocturam (pre-firing), a record linked to the manufacturing process or manufacture of the packaging. The bottling phase put an end to the function of the stamp, passing the protagonist to the tituli picti that guaranteed the commercialization and consumption of the packaged product. The latter ceased to have legal validity when the product was opened, when the graffiti post cocturam appeared to rationalize consumption. Below we show (Figure 2) the most minimal epigraphic system of the oil amphora Dressel 20, taking as an example the Antonine productions of the middle of the 2nd century AD.

\section{The case of oil amphora Dressel 20}

At the base of the amphora, an ante cocturam calendar graffito type is drawn (A1) (Berni 2018), and in the curvature of the right handle is the imprint of the stamp (A2). In both cases, the two pottery registers are linked, as we have already said, to the craft activity of the figlina. The set of tituli picti (B1) is organized with the Greek letters indicated by Dressel in CIL XV, having been written frontally with brush and calamus on the neck and the upper bell of the amphora. These painted inscriptions were written during the bottling phase to label the product with the description of the properties of the content, so they should be considered as the official labelling of the oil amphora in Hispania. Finally, the post cocturam graffiti (B2) may appear incised on different parts of the surface of the amphora. Graffiti of first use are known, mainly in military contexts of Germania and Britannia, that relate to the product originally packaged, as well as other types of graffiti related to the reuse of these containers, whole or cut, for another purpose. The example illustrated with the inscription 'COR M VII', incised in the circumference of the rim of the amphora, comes from the Flavian military fortress of the Dutch city of Nijmegen (Berni 2017: 311, no.331), and is composed of an abbreviated name Cor() and the capacity figure of seven modii. We understand that Cor() was the final owner of that content and the figure of VII modii is a first indication of the oil extracted from the amphora for its distribution and consumption among the soldiers of a detachment.

The aforementioned graffito has recently been published in the first general corpus of amphora epigraphy of Nijmegen, which has a large catalogue of post cocturam graffiti from military contexts. In the following illustration (Figure 3) we group other examples from this catalogue that will help us to better understand the organization and functionality of this type of inscription.

The first inscription 'KAPRI M VII SI' was incised on the mouth of a Flavian amphora and reads 'Kapri m(odii) VII s(extarius) I', with the name of the final owner of the product written above the volume of olive oil subtracted from the amphora (61.825 liters) (Bogaers and Haalebos 1989: 56, fig. 7.1; Berni 2017: 311, no.332). The next inscription '> PAVLI MACEDONIS', also on the top edge of a Flavian amphora, only has the nominal element (Bogaers and Haalebos 1989: 56, fig. 7.2; Berni 2017: 302, no.282). Even so it is of great scientific interest, as it helps us to better understand, with a particular example, the system of distribution of food within the Roman legions stationed in Germania, with Macedo being the final recipient of the oil to be distributed among the soldiers of the centuria of Paulus. The last example belongs to an amphora of the third quarter of the 2nd century AD (Berni 2017: 313, no.337), has no nominal element, and follows the more usual pattern for this kind of record. The greater unit of VII modii appears on the lip and the fractional number of XIIII sextarii in the curvature of the handle, to make a 

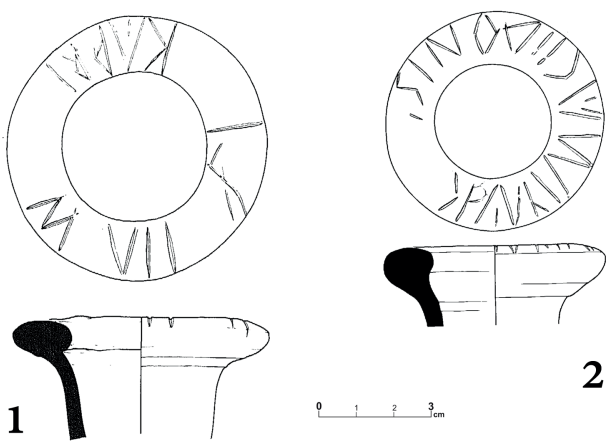

2

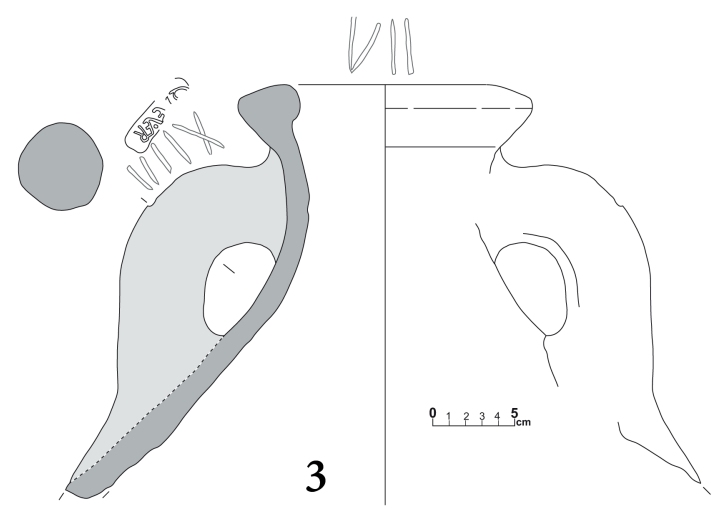

FiguRE 3. POST COCTURAM GRAFFITI FROM MILITARY CONTEXT FROM NIJMEGEN.

total of 68.936 liters. Taking into account that most of the Antonine Baetican amphorae follow a true standard of 216 Roman librae (Rodríguez Almeida 1981: 133-151), which is equivalent to the total capacity of 9 modii or 78.768 litres, $87.5 \%$ of the oil packaged in Baetica would have been subtracted at Nijmegen in the first instance.

The official inscriptions of the Hispanic oil amphorae are always written in indelible black ink, which in the Roman world took the generic name atramentum for its colour (Aguilera and Berni 1998: 264-266). These inscriptions play a role similar to the adhesive paper labels on our plastic or glass bottles, so they were also placed during the canning process of the product being packed. The epigraphic system of the Dressel 20 amphorais well known from Monte Testaccio thanks to the work of Dressel in CIL XV and later by Rodríguez Almeida (Rodríguez Almeida 1984: 175ff). As Dressel noticed, the inscriptions painted on Dressel 20 are organized with five elements which, unlike other amphorae, share two important features: they are always written in a fixed position and their meaning is constant (Figure 2). On the neck the element $\alpha$ gives the tare of the amphora (c. 30kg). In the upper part of the belly the Greek letter $\gamma$ gives the net weight of the olive oil (c. 70kg). The sum of these two figures gave the total weight of the oil amphora (c. 100kg), a value obtained from a simple calculation that was used to organize the transport of goods by water and land routes. In the upper bell is $\beta$ with the name of the merchant, or even and often with a society of olearii, related or not, in possession of the merchandise. The only cursive inscription is $\delta$, written with calamus transversely under the right handle, with useful data on the bottling and strict fiscal control. This is the only fixed inscription that will evolve over time, becoming increasingly long and detailed in a number of elements. At the base of the handle, next to the previous or sometimes almost overlapping element, a fifth inscription called $\varepsilon$ appears frequently, a numerical figure of unknown significance that Dressel considered as an anomaly of these oil amphorae.

At this point, it is useful to make a series of observations on specific important aspects of the function and meaning of this epigraphy, to clarify or specifying some ideas that have been debated by researchers in recent years, although with different points of view. The analysis of certain characteristics inherent in these inscriptions take into consideration the autopsy of the epigraphic document itself, which has not always been carefully examined in reference to certain hypotheses.

One of the most peculiar features of the Dressel 20 amphora tituli picti system is that its five elements are written in fixed positions and their meaning remained constant. This can be explained by the fact that the Baetican olive oil was a product of strategic consumption for the Roman State, as demonstrated through the archaeological record, or on the famous and monumental Monte Testaccio of Rome, the garbage dump of the Annona, or through the hundreds of thousands of fragments of these amphorae in German and British military sites (Remesal 1986; Carreras and Funari 1998). In parallel, there was a large and high private trade that allowed for the arrival of Baetican oil in any corner of the Roman Empire, as we also demonstrated with the collection of this material in the territory of presentday Catalonia (Berni 1998). Roman State consumption captured the largest volume of the market, but left the private sector enriched by trade, to the extent that this group became organized as a legal entity under the name 'corpus oleariorum'. (Tabales Rodríguez and Jiménez Sancho 2001). Some of the merchants, who carried out commercial activity with the annona of Rome, became publicly known from the Antonine dynasty, through characters who are also registered in the tituli $\beta$ of Testaccio, with the title or honor of 'Diffusor olei ad annonam urbis' (Chic et al. 2001). We believe that this peculiar and orderly epigraphic system was the product of the need to establish rules of control on the labelling of oil that would be understandably useful for the collective olearii and the administration of the Roman State. This is an epigraphic system of consensus between public and private bodies as two different legal entities that were joined in a common commercial enterprise.

The following unique feature of the Dressel 20 amphora epigraphic system is known, although with a greater incidence, in other Hispanic amphorae productions, 

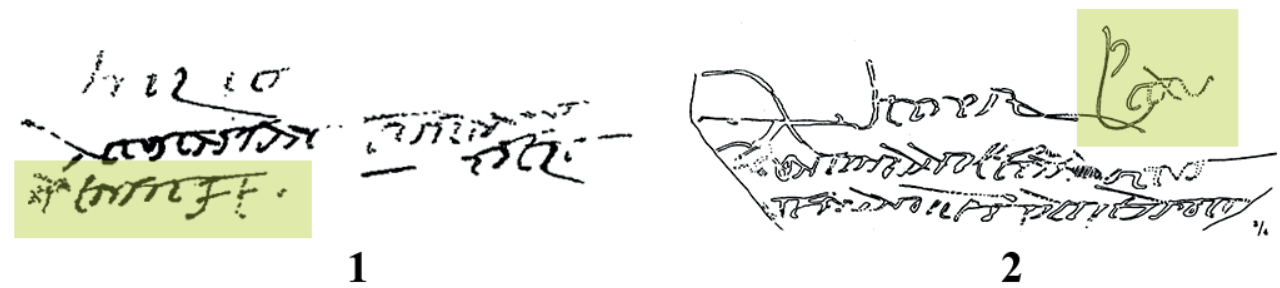

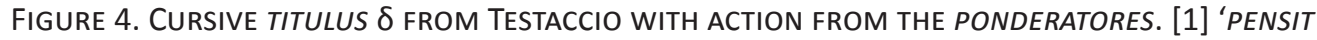 FE[---]' (Rodríguez AlmeidA 1994: 62, No.63). [2] 'P(ONDO) CCXV' (CIL XV 4392).}

such as the tituli picti of the fish-sauce amphorae that have different structures and more complex and irregular records. We refer to the fast writing system that conditioned the epigraphic formulas and the technique of calligraphy for inscriptions. This characteristic is clearly expressed in the epigraphic composition of the Dressel 20 amphora. The enormous volume of the production and trade of Baetican olive oil required a practical and quick system of bottling, for the distribution every year of thousands of globular amphorae during the season of the diffusio olearia that was carried out between spring and summer. The tituli picti were written in positions indicated on the amphora (Figure 2) with the aid of a writing box (pictaccium) that was impregnated with a liquid which helped to smooth the surface and to fix the ink in any position on the surface of the object. First the empty amphora was weighed, then a brush was used to mark in $\alpha$ the tare in Roman librae. Then, with the amphora suspended on the Roman steelyard it was filled with oil to obtain the net weight of the product packed in $\gamma$. Then $\delta$ was written with a short calamus and with cursive writing under the right handle of the amphora. Then, with a small brush, the name of the owner of the merchandise was registered frontally in the upper part of the globular body. The bottling process ended with the closing of the Dressel 20 amphora mouth, using a round ceramic lid (operculum) with a thick layer of lime mortar that shaped the stopper. The cap in its fresh state was marked with a security stamp bearing the name of the character of $\beta$, in order to security seal the product and ensure that the amphora were not open without the permission of their owner (Berni and Gorostidi 2013).

The busy activity of the diffusio olearia forced the development of a fast and efficient bottling system to speed up waiting times. Weighing the amphorae saved a great deal of time and effort, since filling them with a measure of capacity would have required the use of calibrated containers to carry out this calculation, which would have slowed down the work. Note that many tituli $\delta$ carry the abbreviation $p$ (ondo) followed by the numeral $\gamma$ (Figure 4, no.2). In some cursive inscriptions from the 3rd century $\mathrm{AD}$ the single letter $\mathrm{p}$ appears in front of servile names written in the Latin nominative case, or even with the total development of pensit into the verb pendo, going against the general rule (Figure 4, no.1). The reason proposed by Rodríguez Almeida is that the verb pendo was used in a transitive sense applied to the character linked to the action of weighting, whereas the verb pondero followed by the numeral $\gamma$ was intransitively applied to the weight of the amphora (Rodríguez Almeida 1994: 62, no.63).

In the paleography of the tituli $\alpha$ and $\gamma$, the particularity of writing the weights quickly, with frequently repetitive values, drawn by means of a rectangular section brush, results in signs that resemble musical notes by the simple fact of combining thick horizontal strokes with thin verticals (Dressel 1878: 163). Dressel called them 'Hispanic numerals', although in reality we now know that they only occurred in Baetica (Aguilera and Berni 1998). To carry out this writing the values 1, 5, 10, 50 and 100 were used combined. From the beginning of the 2nd century $\mathrm{AD}$ the ductus was continued, linking the letters to each other, which made it possible to write the numbers more quickly, trying to raise the hand as few times as possible. Another feature, a little strange but effective, was to put small units in front of large ones to subtract quantities. Thus the construction of the final number was shorter in signs: CXCVIII instead of CLXXXXVIII (CIL XV 4491), XCI instead of LXXXXI (CIL XV 4491). In addition, it also helped to correct the final calculation without having to repeat the whole operation by rewriting the result: ICI to return to C (CIL XV 4044), IXCI to subtract the unit from further obtaining XC (CIL XV 4491).

Of all the inscriptions on the Dressel 20 amphora the cursive titulus $\delta$ was the one that evolved the most over the years. During the 1st century AD they are simple, with a few elements written in a single line (a name in the genitive, another in the nominative, the abbreviation $\grave{A}$, the value of $\gamma$ ). During Hadrian's reign new elements appear ( $\mathrm{R}$ barred, a city name, a neutral name, other numerals, the abbreviation $a c c())$. Some years later with Antoninus Pius consular dating is introduced. With the reform of Septimius Severus new elements appear and others disappear. The longest forms occupy three lines of writing. The way of making the cursive inscription was also thought to save time when written with a synthetic language based on keywords, mostly abbreviated. The elements followed a logical order, proper names were governed by the grammatical case, and to avoid confusion about the context of the names abbreviated attributes were added in front. In this way the cursive titulus $\delta$ did not lose or alter their meaning, making it possible to reconstruct the original full document knowing the writing system codex. 


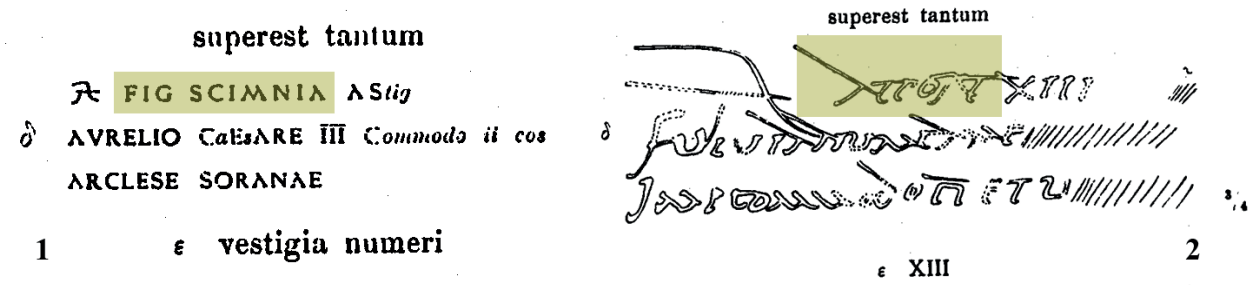

FIgURE 5. TWO CURSIVE TITULI PICTI FROM TESTACCIO WITH THE INDICATION OF THE BOTTLING LOCATION IN THE VALLEY OF THE GUADALQUIVIR (CIL XV 4350 AND 4371).

The cursive $\delta$ was an official fiscal registration of the bottling process (Dressel 1878: 169), as a result of the sale-purchase of the oil between two physical entities, the producers or hoarders and the agents of the merchant. Dressel 20 amphorae were bottled in facilities specially prepared to carry out this busy activity of the diffusio olearia in the mare apertum months. We know from the inscriptions of Testaccio that some Stationes fisci were annexed to the figlinae or within the fundi figlinarum on the banks of the rivers Guadalquivir and Genil, if it was possible to have the appropriate port infrastructures to withstand the high volume of merchandise traffic. Rodríguez Almeida published, some years ago, an illustrated scheme that is very useful for understanding the dynamics of this economic activity in Baetica (Rodríguez Almeida 1993: 101, fig. 2), connecting with arrows the fundi olearii of the inland province with the bottling officinae next to the riverside potteries. In the following illustration (Figure 5) we present two examples from Testaccio with the explicit mention of the place where the olive oil was packaged. In the titulus on the left it reads ' $R$ fig( ) Scimnia() As[tig](is) / Aurelio Cae[s]are III C[ommodo II co(n) s(ulibus)] / arcle(n)se Soranae' with consular date of the year AD 161 (CIL XV 4350). The one on the right is dated $179 \mathrm{AD}$ and reads 'R at port(um) XIII [---] / fulvianum Camp[--- ------] / Imp(eratore) Commodo II et V[ero II co(n)s(ulibus)]'.

It should be noted first that the interpretation of these synthetic records will depend on the theoretical model used by each researcher. To date, there is still no consensus on the meaning and formulation of the different elements that shape these cursive inscriptions. There are many scientific theories, sometimes conflicting (Rodríguez Almeida 1984: 175ff ; Chic 1986; Remesal 1986: 21ff; Liou and Gassend 1990: 208; Liou and Tchernia 1994). We cannot discuss all these issues here, but will focus on certain aspects linked to our own historical questions.

From the titulus $\delta$ of CIL XV 4350 we know that the oil packaging process was carried out in the Astigitanian figlina of the Scimniani family, located in Las Delicias, next to the right bank of the Genil River and near Écija (the Roman city of Astigi) (Berni 2008: 426). The consular dating, which was first introduced in the time of Antoninus Pius, controlled the date on which the tax was paid in the year the oil was bottled.

The letter $\mathrm{R}$ barred, which Dressel believed at first to be the abbreviation Rat(ionis), appears on most of the inscriptions from the middle of the 2nd century AD almost always accompanying a city name from the Guadalquivir valley (Astigis, Hispalis, Corduba), the Baetica coast (Lacca, Malaca, Sel), or the border of Tarraconensis (Castulo). Dressel changed his mind (CIL XV: 562), influenced by Mommsen and suggested reading $R$ (ecognitum) when he saw an official character in the state controlled operation of the oil trade. Rodríguez Almeida suggested reading $R$ (ecensitum) (Rodríguez Almeida 1972: 126-128), which in the Roman administrative language has the value of enumerating, counting and census, after taking the phrase 'ad oleum afrum et hispanum recensendum' of the hispalense epigraph with the cursus honorum of the praefectus annonae Ulpius Saturninus (CIL II 1180). In Remesal's opinion (Remesal 1986: 21-22) the $R$ would read as recognitum, and next to the name of the cities, which he interprets as the fiscal district from which the amphora was issued, the form translated into modern terminology could have the meaning: 'Checked in the district of Astigi ....

This last hypothesis conflicts with the documentation of Testaccio, as we know several examples where the location of the oil packaging does not correspond territorially with the administrative name of the city where the fiscal check was supposed to be performed. For example, the Astigitanus check CIL XV 4294 is associated with the stamp SNR of La Catria in the conventus Hispalensis. Or the most striking case, because of the geographic distance, that we find in CIL XV 4031, is in Corduba on an amphora from the territory of Hispalis with the stamp DATSCOL of Azanaque-Castillejo figlina.

Remesal also proposed that the name of the city be the capital of the administrative convent where the fiscal check was carried out, but we have among the names of coastal cities Lacca, Malaca, Sel (CIL XV 3926, 4203; Testaccio VI nos463 and 479) which was part of the conventus Gaditanus. In addition, there is a cursive mark of Castulo (CIL XV 4137), belonging to the conventus Carthaginensis, for a Tarraconensis oil that had to be transported for packaging, after covering a great distance, at some navigable point of the Guadalquivir river below the colonia of Corduba. Therefore, we believe that these city names would not allude to the administrative capital of the place where the fiscal check was carried out, but to the fiscal districts of the oil to be bottled. We believe it has to do with an attempt to eradicate fiscal fraud, which 
would have been generated, for example, by packaging oil from Corduba at a fiscal statio in the territory of Hispalis. Perhaps that is the reason why Dressel's initial proposal on $R$ barred as an abbreviation of Rat(io) can be rescued, a term that is neither alien nor incompatible with oil trade (The tituli $\beta$ of 3rd century AD of the 'Fisci rationis patrimoni provinciae Baeticae': CIL XV 4124, or 'Fisci rationis patrimoni provinciae Tarraconesis': CIL XV 4134-4137), if it is understood that the tax generated by the sale-purchase of the oil was to be entered in the Fiscus, the personal chest of the emperors of Rome, with the place of origin of the packaged product. There are other tituli picti $\beta$ of the Ratio Fisci, dated around AD 220-224, that include at the end of the inscription names of stationes, such as Sel, Sex and $\mathrm{Po}[---]$, which correspond to port towns on the coast of conventus Gaditanus (CIL XV 4142; Testaccio II no.125, 120-127; Martínez et al. 2017).

Returning to the Astigi inscription of CIL XV 4350 (Figure 5.1), in the last line there is a neuter $\operatorname{arcle}(n) s e$ in front of a female name Sorana. The neuter names of the tituli picti $\delta$ have endings - $u m$ and $-e(n)$ se and usually accompany a person's name in the genitive. We, following Dressel, think these names are place names. When they end in -um as in fulvianum (Figure 5.2) they allude to the oil producer, and if they end in $-e(n)$ se the fundus olearius. Remesal (1979) thinks that it is the place where the fiscal check was carried out, but in the amphora of Las Delicias we already have that indication with the name of the figlina Scimniana. On the other hand, if we develop the text of the third line as '(oleum) arcle(n)se Soranae', the genitive name could fit semantically as the owner of the product to be packaged. Remesal (1979; 1986: 22) believes that the characters in the genitive are the publicani in charge of the fiscal control. In this example it could be a woman who may have stocked oil from different fundi olearii.

As regards the inscription CIL XV 4371 (Figure 5.2) a similar formula to the previous one is observed, except that instead of the name of city we have the word 'ad port(um)' that Dressel believed to refer to the portus of Gades (Dressel 1878: 161). For us this indication associated with the neutral fulvianum should be related to the bottling facilities of the Arva river port (Berni 2008: 165), which were annexed to an important sector of the craft industry that has left its print on the amphorae with the PORT-ARVA stamps (Berni 2008: 287, table 45). We know that the Fulvii of Arva practiced different economic activities linked to agricultural production (CIL II 1064, Suppl.: 837), such as the manufacture of amphorae (Berni 2008: 194-195), and the oil trade (CIL XV 3876).

\section{Amphorae for fish products}

Here we gather the main amphorae for fish-products from the Iberian peninsula, namely Dr. 7-11, Dr. 12, Beltrán II, Dr. 14, Schoene VII (also called Pompeii VII). From the end of the Republican period and throughout the early Roman period, these amphorae were used to transport and trade fish-salted products and sauces. Within these two categories are all kinds of fish, from tuna to sardines, and for the latter four varieties of products, known as garum, liquamen, muria, and allec.

The majority of scholars now follow the pattern of organization of tituli picti proposed by S. Martin-Kilcher (Martin-Kilcher 2002, 2004 and 2011), but there are also other systems, notably that used by R. Étienne and Fr. Mayet (Étienne and Mayet 2002: 211-214), who apply the codification of $\mathrm{H}$. Dressel to fish amphorae for reading the inscriptions on Dressel 20 oil amphorae.

The diagram proposed by S. Martin Kilcher corresponds to Figure 6, organized from letters $\mathrm{A}$ to $\mathrm{H}$, with primary inscriptions from the letters A to $\mathrm{E}$ and secondary inscriptions from $\mathrm{F}$ to $\mathrm{H}$.

These letters each correspond to specific information:

We will find in the first line the name of the product, often abbreviated, and this is one of the major differences with wine and oil amphorae, for which the nature of the content is never indicated. This implies of course that there was little doubt that they were transporting this type of foodstuff. For amphorae for fish products, this is also due to the fact that a wide variety of preparations could be placed in these containers: garum, liquamen, muria, and other products whose meaning is not yet fully understood: lymp, laccatum... We do not have enough space here to dwell on the meaning of all the inscriptions found on line A, and for which there is an abundant bibliography, including recently (for example papers of U. Ehmig, more precisely Djaoui 2016; Bernal-Casasola and Domínguez Bella 2011; Quillon 2016).

The mention of the product is sometimes accompanied by a product-specific qualifier, such as vet for vet(us) or $\arg$ for $\arg ($ utus).

On the lines of group B are first qualifiers on the quality of the product: excellens or flos being the most common, and one also finds penuar or summaur. The number of years of aging can be found, though not systematically, for example in the AIIA formula that indicates two years.

Line $C$ corresponds to a figure, which almost certainly corresponds to a unit of measure of the amphora content, and it is assumed that it must be a unit of measure in pounds, although sometimes figures have very high values (Martin-Kilcher 1994: 420-421; Botte 2009: 162).

The inscription of line D will give us the name of the merchant, the negotiator, sometimes in a simple form but more frequently in the form of duo or tria nomina.

Finally, under the handle, perpendicular to the group of inscriptions $C$ to $D$, there is the inscription $E$, composed of a number and / or a name whose meaning is not obvious 


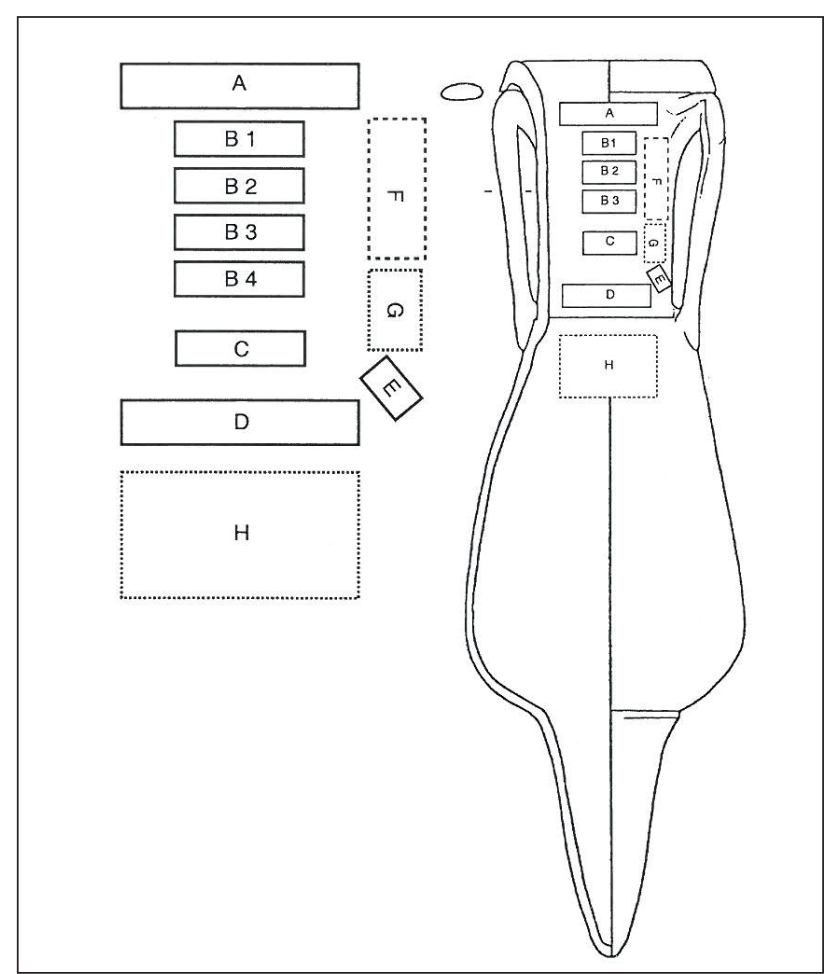

FIGURE 6. ORGANIZATION OF THE TITULI PICTI ON FISH AMPHORAE (MARTIN-KILCHER 2002).

because it is often written with small cursive letters. It is generally considered to be a control mark written by a negotiator's representative.

Finally there are the secondary inscriptions $\mathrm{F}$ to $\mathrm{H}$. For $F$ and $G$, S. Martin-Kilcher suggests the signature of a merchant and the number of amphorae that he transported between the port of arrival of the containers and the consumption sites (Martin-Kilcher 2002: 345-346). Others suggest the name of the producer and the number of amphorae leaving the fish-salting factory (Étienne and Mayet 2002: 213-214).

Finally the last inscription $\mathrm{H}$ refers to the owner of the amphora once it arrived at its destination. It may have been painted under the line $\mathrm{D}$, sometimes even over the group of primary inscriptions $\mathrm{A}$ to $\mathrm{D}$, and it is clear that it is a different hand, sometimes even in a different colour.

\section{Bibliography}

Aguilera Martín, A. and Berni Millet, P. 1998. Las cifras hispánicas. In J. Mateu Ibars (ed.), Calligraphia et tipographia. Arithmetica et numerica. Chronologia: 257-282. Barcelona, Universitat de Barcelona.

Bernal-Casasola, D. and Domínguez Bella, S. 2011. Colorantes y pigmentos en las pesquerías hispanorromanas. CUPAUAM. Cuadernos de Prehistoria y Arqueología de la Universidad Autónoma de Madrid 37-38: 671-685.

Berni Millet, P. 1998. Las ánforas de aceite de la Bética y su presencia en la Cataluña romana. Instrumenta 4. Barcelona, Universitat de Barcelona.
Berni Millet, P. 2008. Epigrafía anfórica de la Bética. Nuevas formas de análisis. Instrumenta 29. Barcelona, Universitat de Barcelona.

Berni Millet, P. 2017. Chapter 8. Amphorae-Epigraphy: Stamps, Graffiti and Tituli Picti from Roman Nijmegen. In C. Carreras and J. van der Berg (eds), Amphorae from the Kops Plateau (Nijmegen): trade and supply to the Lower-Rhineland from the Augustan period to AD 69/70. Archaeopress Roman Archaeology 20: 185-282, 289343. Oxford, Archaeopress.

Berni Millet, P. 2018. Calendar graffiti on Dressel 20 amphoras. Asiaticus: another paradigmatic case with a new find from Brijuni (Croatia). in T. Bezeczky (ed.), Amphora research in Castrum Villa on Brijuni Island. Archäologische Forschungen 28: 143-172.Vienna, Austrian Academy of Sciences Press.

Berni Millet, P. and Gorostidi Pi, D. 2013. C. Iulius Valerianus et C. Iulius Iulianus: mercatores del aceite bético en un signaculum de plomo para ánforas Dressel 20. Journal of Roman Archaeology 26: 167-189.

Bogaers, J. E. and Haalebos, J. K. 1989. Opgravingen op het terrein van het voormalige Canisiuscollege, 19871989. Overdruk uit Nuaga 36: 49-60.

Botte, É. 2009. Salaisons et sauces de poissons en Italie du Sud et en Sicile durant l'Antiquité. Collection du Centre Jean Bérard 31. Archéologie de l'artisanat antique 1. Naples, Centre Jean Bérard.

Callender, M. H. 1965. Roman Amphorae, with index of Stamps. Oxford, University Press.

Carreras Monfort, C. and Funari, P. P. A. 1998. Britannia y el Mediterráneo. Instrumenta 5. Barcelona, Universitat de Barcelona.

Chic García, G. 1986. El comercio del aceite de la Astigi romana. Habis 17: 243-264.

Chic García, G., García, E., Romo, A. and Tabares, M. A. 2001. Una nueva inscripción annonaria de Sevilla: M. Iulius Hermesianus, diffusor olei ad annonam urbis. Habis 32: 353-374.

CIL II: Corpus Inscriptionum Latinarum, vol. II. Inscriptiones Hispaniae Latinae, A. Hübner, A. (ed.), Berlin, 1869; Inscriptionum Hispaniae Latinarum Supplementum, Hübner A. (ed.), Berlin, 1892.

CIL XV: Corpus Inscriptionum Latinarum, vol. XV. Inscriptiones urbis Romae Latinae. Instrumentum domesticum, Pars II, fasc. 1, H. Dressel (ed.), Berlin, 1899.

Colls, D., Étienne, R., Lequément, R., Liou, B. and Mayet, F. 1977. L'épave Port-Vendres II et le commerce de la Bétique à l'époque de Claude. Archaeonautica 1.

Djaoui, D. 2016. The myth of 'Laccatum': a study starting from a new titulus on a Lusitanian Dressel 14. In I. V. Pinto, R. R. de Almeida and A. Martin (eds), Lusitanian Amphorae: Production and Distribution. Roman and Late Antique Mediterranean Pottery 10: 117-127. Oxford, Archaeopress.

Dressel, H. 1878. Ricerche sul Monte Testaccio. Annali dell'Istituto di Corrispondenza Archeologica 50: 118-192.

Étienne, R. and Mayet, F. 2002. Salaisons et sauces de poisson hispaniques. Trois clés pour l'économie de l'Hispanie romaine, II. Paris, de Boccard. 
Grenier, A. 1934. Archéologie gallo-romaine (Manuel d'archéologie préhistorique, celtique et gallo-romaine de J. Déchelette, VI). Deuxième partie : L'archéologie du sol : 601642. Paris, A. Picard.

Liou, B. and Gassend, J.-M. 1990. L'épave Saint-Gervais 3 à Fos-sur-Mer (milieu du IIer siècle ap. J.-C.). Inscriptions peintes sur amphores de Bétique. Vestiges de la coque. Archaeonautica 10: 157-264.

Liou, B. and Tchernia, A. 1994. L'interprétation des inscriptions sur les amphores Dressel 20. In Epigrafia della produzione e della distribuzione. Actes de la VIIe Rencontre franco-italienne sur l'épigraphie du monde romain (Rome, 5-6 juin 1992). Collection de l'École française de Rome 193: 133-156. Rome, École française de Rome.

Martin-Kilcher, S. 1994. Die römischen Amphoren aus Augst und Kaiseraugst, 2-3. Die Amphoren für Wein, Fischsauce, südfrüchte (Gruppen 2-24) und Gesamtauswertung. Forschungen in Augst 7/2-3. Augst, Römermuseum Augst.

Martin-Kilcher, S. 2002. Lucius Urittius Verecundus, négociant à la fin du Ier siècle, et sa marchandise découverte à Mayence. In L. Rivet and M. Sciallano (eds.), Vivre, produire et échanger : reflets méditerranéens, Mélanges offerts à Bernard Liou. Archéologie et Histoire romaine 8:343-353. Montagnac, Éd. Monique Mergoil.

Martin-Kilcher, S. 2004. Fischsaucen: Pinselaufschriften und römische Amphoren. In J. Remesal Rodríguez (ed.), Epigrafía anfórica. Instrumenta 17: 245-257. Barcelona, Universitat de Barcelona.

Martin-Kilcher, S. 2011. Formes d'amphores et contenus au Haut-Empire, points de repère et questions. In SFECAG, Actes du Congrès d'Arles: 417-426. Marseille, Société Française d'Étude de la Céramique Antique en Gaule.

Martínez Rodríguez, F., Márquez Cruz, M., Sarompas Cazorla, C. E. 2017. Tituli picti en ánforas olearias béticas alusivos a la statio sel y a la statio sex, hallados en el Monte Testaccio de Roma, y su contexto geo-histórico. Cuadernos de prehistoria y arqueología de la Universidad de Granada 27: 373-397.
Mayet, F. 1986. Les figlinae dans les marques d'amphores Dressel 20 de Bétique. In Hommage à Robert Étienne. Publications du Centre Pierre Paris 17. Revue des études anciennes 88: 285-305.

Quillon, K. 2016. Les amphores à salaisons et sauces de poissons de Bétique et de Tarraconaise : typologie et contenu (fin de la République - Haut-Empire). Unpublished PhD Thesis, Aix-Marseille Université.

Remesal Rodríguez, J. 1977-78. La economía oleícola bética: nuevas formas de análisis. Archivo Español de Arqueología 50-51: 87-142.

Remesal Rodríguez, J. 1979. Recensión a Archaeonautica I (1977). Archeologia classica 31: 379-389.

Remesal Rodríguez,J. 1986. La annona militarisy la exportación de aceite bético a Germania. Madrid, Universidad Complutense.

Rodríguez Almeida, E. 1972. Novedades de epigrafía anforaria del Monte Testaccio. In Recherches sur les amphores romaines. Actes du Colloque de Rome (4 mars 1971) Collection de l'École française de Rome 10: 107-241. Rome, École française de Rome.

Rodríguez Almeida, E. 1981. Varia de Monte Testaceo. Cuadernos de Trabajos de la Escuela Española de Historia y Arqueología en Roma 15: 105-164.

Rodríguez Almeida, E. 1984. Il Monte Testaccio: ambiente, storia, materiali. Rome, Quasar.

Rodríguez Almeida, E. 1993. Graffiti e produzione anforaria della Betica. In W. V. Harris (ed.), The inscribed economy: production and distribution in the Roman empire in the light of instrumentum domesticum: the proceedings of a conference held at the American Academy in Rome on 10-11 January, 1992. Journal of Roman Archaeology Supplementary Series 6: 95-107. Ann Arbor, University of Michigan.

Rodríguez Almeida, E. 1994. Los tituli picti. In J. M. Blázquez Martínez (ed.), Excavaciones arqueológicas en el Monte Testaccio (Roma): 36-129. Madrid, Instituto de Conservación y Restauración de Bienes Culturales.

Tabales Rodríguez, M. A. and Jimenez Sancho, A. 2001. Hallazgo de una nueva inscripción referente al cuerpo de olearios en el Alcazar de Sevilla. Habis 32: 375-385.

Thévenot, E. 1951. Una familia de negociantes de aceite establecida en la Bética en el siglo II: los Aeli Optati. Archivo Español de Arqueología 25: 225-231. 